Available online at http://journal.stkip-andi-matappa.ac.id/index.php/histogram/index

Histogram : Jurnal Pendidikan Matematika 2 (2), 2018, 195-206

\title{
PENGEMBANGAN PERANGKAT PEMBELAJARAN MATEMATIKA BERBASIS PPK YANG BERORIENTASI PADA KECAKAPAN ABAD-21
}

\author{
Ulfiana Yusuf $^{1}$, Andi Tenriawaru ${ }^{2}$ \\ Dosen Program Studi Pendidikan Matematika \\ STKIP YPUP Makassar ${ }^{1,2}$ \\ * Corresponding Author. Email: yusufulfiana@yahoo.com \\ Received: 1 September 2018; Revised: 21 September 2018; Accepted: 27 September 2018
}

\begin{abstract}
ABSTRAK
Penelitian ini bertujuan untuk mengembangkan perangkat pembelajaran berbasis penguatan pendidikan karakter (PPK) yang berorientasi pada kecakapan abad 21 yang valid, efektif, dan praktis pada pokok bahasan Bilangan yang meliputi Buku Siswa, LKPD, dan RPP. Subjek penelitian ini adalah siswa kelas VII SMP Negeri 7 Binamu dengan jumlah siswa sebanyak 20 orang. Penelitian ini merupakan penelitian pengembangan dengan prosedur menggunakan model 4-D yang meliputi empat tahap yaitu pembatasan, perancangan, pengembangan, dan penyebaran. Perangkat pembelajaran berbasis penguatan pendidikan karakter yang berorientasi pada kecakapan abad 21 yang telah dikembangkan telah divalidasi dan mengalami revisi berulang kali sehingga didapatkan hasil yang maksimal dan layak untuk digunakan. Hasil dari ujicoba terbatas menunjukkan bahwa perangkat pembelajaran bersifat efektif dan praktis, yaitu (1) skor rata-rata yang diperoleh siswa pada tes hasil belajar adalah 80,5 yang menunjukkan bahwa ketuntasan klasikal tercapai, (2) siswa jadi lebih aktif dalam proses pembelajaran; (3) pada umumnya siswa memberikan respon yang positif terhadap perangkat pembelajaran yang digunakan; dan (4) Tingkat kemampuan guru dalam mengelola proses pembelajaran termasuk dalam kategori tinggi, artinya penampilan guru dapat dipertahankan.
\end{abstract}

Kata Kunci: Penguatan Pendidikan Karakter, Kecakapan abad-21

How to Cite: Yusuf, U., Tenriawaru, A. (2018). Pengembangan Perangkat Pembelajaran Matematika Berbasis Ppk Yang Berorientasi Pada Kecakapan Abad-21. Histogram: Jurnal Pendidikan Matematika, 2(2), 195-206. doi: http://dx.doi.org/10.31100/histogram.v2i2.232

Permalink/DOI:

http://dx.doi.org/10.31100/histogram.v2i2.232

\section{PENDAHULUAN}

Menteri Pendidikan dan Kebudayaan Republik Indonesia dalam sambutannya pada modul pelatihan penguatan pendidikan karakter (Tim PPK Kemdikbud, 2017), mengatakan bahwa bangsa besar adalah bangsa yang memiliki karakter kuat, yang tumbuh dan berkembang dari pendidikan yang menyenangkan dan lingkungan yang menerapkan nilainilai baik dalam seluruh sendi kehidupan berbangsa dan bernegara. Hanya dengan karakter This is open access article under the CC-BY-SA-license.

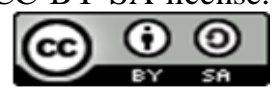




\section{Histogram: Jurnal Pendidikan Matematika, 2 (2), 2018 - 196 Ulfiana Yusuf, Andi Tenriawaru}

yang kuat dan kompetensi yang tinggilah jati diri bangsa menjadi kokoh, kolaborasi dan daya saing bangsa meningkat sehingga mampu menjawab berbagai tantangan era abad 21 . Untuk itu, pendidikan nasional harus berfokus pada penguatan karakter di samping pembentukan kompetensi.

Selanjutnya dikatakan bahwa penguatan karakter bangsa menjadi salah satu butir Nawacita yang dicanangkan Presiden Joko Widodo melalui Gerakan Nasional Revolusi Mental (GNRM). Komitmen ini ditindaklanjuti dengan arahan Presiden kepada Menteri Pendidikan dan Kebudayaan untuk mengutamakan dan membudayakan pendidikan karakter di dalam dunia pendidikan. Atas dasar ini, Kementerian Pendidikan dan Kebudayaan mencanangkan Penguatan Pendidikan Karakter (PPK) secara bertahap mulai tahun 2016.

Penguatan Pendidikan Karakter bukanlah suatu kebijakan baru sama sekali karena sejak tahun 2010 pendidikan karakter di sekolah sudah menjadi Gerakan Nasional. Satuan pendidikan menjadi sarana strategis bagi pembentukan karakter bangsa karena memiliki sistem, infrastruktur dan dukungan ekosistem pendidikan yang tersebar di seluruh Indonesia mulai dari perkotaan sampai pedesaan. Sudah banyak praktik baik yang dikembangkan sekolah, namun masih banyak pekerjaan rumah yang harus dituntaskan untuk memastikan agar proses pembudayaan nilai-nilai karakter berjalan dan berkesinambungan. Selain itu, sangat diperlukan kebijakan yang lebih komprehensif dan bertumpu pada kearifan lokal untuk menjawab tantangan zaman yang makin kompleks, mulai dari persoalan yang mengancam keutuhan dan masa depan bangsa sampai kepada persaingan global. Kebijakan ini akan menjadi dasar bagi perumusan langkah-langkah yang lebih konkret agar penyemaian dan pembudayaan nilai-nilai utama pembentukan karakter bangsa dapat dilakukan secara efektif dan menyeluruh (Tim PPK Kemdikbud, 2017).

Penataan kembali atau transformasi pendidikan nasional Indonesia dapat dimulai dengan menempatkan kembali karakter sebagai ruh atau dimensi terdalam pendidikan nasional berdampingan dengan intelektualitas yang tercermin dalam kompetensi. Dengan karakter yang kuat-tangguh beserta kompetensi yang tinggi, yang dihasilkan oleh pendidikan yang baik, pelbagai kebutuhan, tantangan, dan tuntutan baru dapat dipenuhi atau diatasi. Oleh karena itu, selain pengembangan intelektualitas, pengembangan karakter peserta didik sangatlah penting atau utama dalam sistem pendidikan nasional Indonesia.

Sekolah sebagai garda terdepan dalam peningkatan mutu pendidikan mempunyai

peran penting membentuk karakter siswa. Pendidikan karakter yang dicanangkan Copyright (C) 2018, Histogram: Jurnal Pendidikan Matematika ISSN: 2549-6700 (print), ISSN 2549-6719 (online) 


\section{Histogram: Jurnal Pendidikan Matematika, 2 (2), 2018 - 197 Ulfiana Yusuf, Andi Tenriawaru}

pemerintah melalui kementrian pendidikan diutamakan pada satuan pendidikan SD dan SMP. Sejauh ini pendidikan karakter disekolah telah dilaksanakan, namun belum terstruktur dan belum menyeluruh. Sekolah hanya menekankan pada pengembangan intelektual namun pendidikan karakter belum menjadi prioritas. Hal ini bisa dilihat dari semakin maraknya kecurangan saat ujian nasional, siswa yang menganiaya gurunya, sampai tawuran antar pelajar sebagai akibat dari kurangnya pendidikan karakter.

Pendidikan karakter di Kabupaten Jeneponto sudah dilaksanakan, namun belum terorganisasi dengan baik, hal ini ditunjukkan dengan masih banyaknya guru yang kurang menyisipkan nilai-nilai karakter dalam pembelajaran. Banyak guru yang lupa menyisipkan nilai karakter dalam pembelajaran karena belum ada perangkat pembelajaran yang berbasis PPK. Selain itu, kepala sekolah sebagai pemimpin sekaligus maneger belum menjadikan pendidikan karakter sebagai program prioritas sekolah, guru hanya melakukannya sendiri sesuai kebutuhan dan terkadang hanya jika terjadi pelanggaran pada peserta didik. Selain itu, beberapa guru hanya menekankan pada aspek religius saja namun lupa pada aspek lainnya seperti nasionalis, mandiri, gotong royong dan integritas. Berdasarkan uraian diatas maka penulis akan melakukan penelitian yang berjudul "Pengembangan Perangkat Pembelajaran Matematika Berbasis Penguatan Pendidikan Karakter (PPK) yang Berorientasi pada Kecakapan Abad 21 Siswa Kelas VII SMP Negeri 7 Binamu Kabupaten Jeneponto". tujuan dari penelitian ini adalah menjawab rumusan masalah, tujuan penelitian ini adalah : "Untuk mengetahui tingkat kevalidan, kepraktisan, dan keefektifan perangkat pembelajaran matematika berbasis Penguatan Pendidikan Karakter (PPK) yang berorientasi pada kecakapan abad 21. Adapun manfaat dari penelitian ini yaitu sebagai bahan evaluasi penerapan program Penguatan Pendidikan Karakter (PPK) di Indonesia terkhusus di Kabupaten Jeneponto, sebagai bahan informasi pelaksanaan pelatihan pengembangan perangkat pembelajaran matematika berbasis karakter yang berorientasi pada kecakapan abad 21 di daerah Jeneponto, dan sebagai bahan informasi guru tentang pengembangan perangkat pembelajaran matematika berbasis Penguatan Pendidikan Karakter (PPK).

\section{METODE PENELITIAN}




\section{Histogram: Jurnal Pendidikan Matematika, 2 (2), 2018 - 198 Ulfiana Yusuf, Andi Tenriawaru}

Jenis penelitian ini adalah penelitian pengembangan (Research and Development) yang mengembangkan perangkat pembelajaran berbasis penguatan pendidikan karakter yang berorientasi pada kecakapan abad 21 yang valid, praktis, dan efektif yang terdiri dari Buku Siswa, Rencana Pelaksanaan Pembelajaran (RPP), Lembar Kegiatan Peserta Didik (LKPD), dan Tes Hasil Belajar. Penelitian ini dilaksanakan di SMP Negeri 7 Binamu Kabupaten Jeneponto dengan subjek penelitiaannya adalah siswa kelas VII tahun ajaran 2018/2019 sebanyak 20 orang dengan tiga tahap yaitu : 1) tahap persiapan dengan kegiatan mengembangkan instrument penelitian, 2) tahap pelaksanaan dengan kegiatan melaksanakan pembelajaran berbasis penguatan pendidikan karakter yang beroritentasi pada kecakapan abad 21 selama 7 kali pertemuan, selama proses pembelajaran berlangsung dilakukan pengamatan aktivitas siswa serta kemampuan guru mengelola pembelajaran dan melaksanankan tes akhir, dan 3) tahap analisis data yang diperoleh dari tahap pelaksanaan. Pengembangan perangkat pembelajaran matematika yang digunakan mengacu pada model 4-D Thiagarajan, dengan tahapan-tahapan sebagai berikut : 1) Tahap Pendefinisian untuk mengumpulkan informasi-informasi berkaitan dengan perangkat pembelajaran yang akan dikembangkan serta menetapkan dan mendefinisikan syarat-syarat pembelajaran yang meliputi tujuan pembelajaran dan pembatasan materi pembelajaran, 2) Tahap perancangan untuk merancang perangkat pembelajaran matematika dan instrumen penelitian, 3) Tahapan pengembangan untuk menghasilkan perangkat pembelajaran yang telah direvisi berdasarkan masukan para ahli dan data hasil uji coba, dan 4) Tahap penyebaran namun belum dapat dilaksanakan karena pelaksanaannya hanya berupa ujicoba terbatas saja. Instrument penggumpulan data yang digunakan berupa: 1) lembar respon siswa terhadap kegiatan pembelajaran, 2) lembar pengamatan aktivitas siswa, 3) lembar penggunaan perangkat pembelajaran, dan 4) lembar validasi. Data yang telah dikumpulkan dengan menggunakan instrumen selanjutnya dianalisis secara kuantitatif untuk mengetahui kualitas perangkat pembelajaran yang dihasilkan sudah bersifat valid, praktis, dan efektif. Data yang diperoleh dari hasil validasi oleh para ahli dianalisis untuk mengetahui valid atau tidak perangkat pembelajaran dan data hasil coba terbatas dan hasil observasi di kelas digunakan untuk mengetahui perangkat pembelajaran sudah bersifat praktis dan efektif.

\section{HASIL DAN PEMBAHASAN}

Copyright (C) 2018, Histogram: Jurnal Pendidikan Matematika ISSN: 2549-6700 (print), ISSN 2549-6719 (online) 


\section{A. Hasil Penelitian}

1. Tahap Pendefinisian

Kurikulum yang digunakan di SMP Negeri 7 Binamu adalah Kurikulum 2013 revisi 2017. Konsep-konsep yang dianalisis dalam penelitian ini merupakan konsep dalam materi pokok bahasan Bilangan untuk SMP Kelas VII. Selanjutnya dirumuskan KI dan KD yang diperoleh pada permedikbud no. 24 tahun 2016 tentang kompetensi inti dan kompetensi dasar yang akan dicapai setelah siswa mempunyai pemahaman terhadap konsep tersebut. Kompetensi dasar yang terkait dengan materi bilangan yaitu KD 3.1, 3.2, 3.3, 4.1, 4.2, dan 4.3. Untuk mengukur pencapaian kompetensi tersebut dilakukan analisis indikator pencapaian hasil belajar.

2. Tahap Rancangan

Berdasarkan tahap analisis, peneliti menyusun perangkat pembelajaran pokok Bilangan untuk SMP kelas VII yang meliputi: Buku Siswa, Lembar Kerja Peserta Didik, Rencana Pelaksanaan Pembelajaran (RPP), dan Tes Hasil Belajar. Pada tahap ini dihasilkan rancangan awal rencana pelaksanaan pembelajaran (RPP) untuk 7 kali pertemuan, buku siswa untuk setiap pertemuan, LKPD untuk setiap pertemuan, dan tes hasil belajar beserta kisi-kisi. Format rencana pelaksanaan pembelajaran yang digunakan disesuaikan dengan format rencana pembelajaran dalam Kurikulum 2013 namun dikembangkan sesuai dengan tujuan penelitian yang berbasis penguatan karakter dan berorientasi pada kecakapan abad 21. Format yang di tambah ada pada tahapan langkah-langkah kegiatan pembelajaran, dengan menambahkan Nilai Karakter, Literasi, dan Kompetensi yang dapat dikuatkan. Sedangkan format buku siswa dibuat bergambar sehingga siswa tertarik dan termotivasi untuk belajar serta memuat kegiatan yang menumbuhkan nilai karakter, literasi, dan kompetensi siswa.

3. Tahap pengembangan

a. Penilaian ahli (validasi I)

Validasi para ahli dilakukan untuk melihat semua perangkat pembelajaran yang diperoleh yang mencakup validitas isi, bahasa, dan kesesuaian perangkat pembelajaran terhadap kurikulum yang berlaku. Hasil validitas I para ahli sebagai berikut :

Tabel 1 Rangkuman Hasil Validasi akhir Perangkat Pembelajaran

\begin{tabular}{ccc}
\hline Perangkat & $\begin{array}{c}\text { Skor Rata-Rata } \\
\text { Penilaian }\end{array}$ & Status \\
& & \\
\hline
\end{tabular}


Histogram: Jurnal Pendidikan Matematika, 2 (2), 2018 - 200

Ulfiana Yusuf, Andi Tenriawaru

\begin{tabular}{lll}
\hline Buku Siswa & 3,13 & Valid \\
\hline Lembar Kerja Siswa & 3,11 & Valid \\
\hline Rencana Pelaksanaan Pembelajaran & 3,19 & Valid \\
\hline
\end{tabular}

Sumber: Data Primer, Tahun: 2018

Berdasarkan kriteria kevalidan maka perangkat pembelajaran tersebut telah memiliki derajat validitas yang memadai dan layak untuk diujicobakan. Namun demikian, perangkat-perangkat tersebut menurut saran para ahli masih perlu diperbaiki/ditambah.

b. Hasil uji coba

Sebagaimana yang telah disebutkan sebelumnya bahwa perangkat pembelajaran hasil revisi (draft II) berdasarkan masukan atau saran dari para validator yang selanjutnya diujicobakan pada siswa kelas VII.A SMP Negeri 7 Binamu. Berdasarkan hasil ujicoba tersebut, dilakukan beberapa revisi terhadap Buku Siswa, LKPD, dan RPP.

c. Penilaian Ahli (Validasi II)

Validasi ke 2 para ahli dilakukan kembali untuk melihat semua perangkat pembelajaran yang diperoleh dari hasil uji coba terbatas.Hasil validitas II digunakan sebagai dasar untuk penyempurnaan terhadap produk akhir hasil pengembangan dapat di lihat pada tabel berikut:

Tabel 2 Rangkuman Hasil Validasi Perangkat Pembelajaran

\begin{tabular}{lcl}
\hline \multicolumn{1}{c}{ Perangkat } & $\begin{array}{c}\text { Skor Rata-Rata } \\
\text { Penilaian }\end{array}$ & Status \\
\hline Buku Siswa & 3,60 & Sangat Valid \\
\hline Lembar Kerja Siswa & 3,69 & Sangat Valid \\
\hline Rencana Pelaksanaan Pembelajaran & 3,53 & Sangat Valid \\
\hline
\end{tabular}

Sumber: Data Primer, Tahun: 2018

Dapat disimpulkan bahwa perangkat yang disebutkan pada tabel di atas sudah termasuk dalam kategori "Sangat Valid". Berdasarkan kriteria kevalidan dan sudah tidak ada revisi lagi dari para validator, maka perangkat pembelajaran tersebut telah memiliki derajat validitas yang memadai dan dapat dijadikan sebagai produk akhir hasil pengembangan (Draft akhir).

4. Tahap penyebaran 
Histogram: Jurnal Pendidikan Matematika, 2 (2), 2018 - 201

Ulfiana Yusuf, Andi Tenriawaru

Penyebaran perangkat pembelajaran hanya bersifat sosialisasi secara terbatas kepada Guru SMP Negeri 7 Binamu

\section{B. Analisis Deskriptif Hasil Penelitian dan Pembahasan}

Berdasarkan hasil ujicoba perangkat pembelajaran, data hasil pengamatan aktivitas siswa, respon siswa terhadap kegiatan dan perangkat pembelajaran, data hasil pengamatan aktivitas guru, dan data hasil pengamatan pengelolaan pembelajaran matematika berbasis penguatan karakter yang berorientasi pada kecakapan abd 21 digunakan untuk mengetahui kepraktisan dan keefektifan perangkat pembelajaran matematika berbasis penguatan karakter yang berorientasi pada kecakapan abd 21. Hasil analisis masing-masing data sebagai berikut :

1. Hasil tes belajar siswa

Data menunjukkan bahwa banyaknya siswa yang tidak tuntas belajar yaitu siswa yang memperoleh skor 0 - 69 sebanyak 3 orang dari 20 siswa atau sekitar 15\%. Adapun siswa yang tuntas belajar yaitu memperoleh skor 60 - 100 sebanyak 17 orang dari 20 siswa atau sekitar $85 \%$. Data ini menunjukkan bahwa ketuntasan klasikal tercapai.

2. Data Hasil Pengamatan Pengelolaan Pembelajaran

Data hasil pengamatan pengelolaan pembelajaran selama tujuh kali pertemuan disajikan dalam tabel berikut:

Tabel 3 Data Pengelolaan Pembelajaran Matematika

\begin{tabular}{|c|c|c|c|c|c|c|c|c|c|}
\hline \multirow{2}{*}{ Aspek Pengamatan } & \multicolumn{7}{|c|}{ Pertemuan ke- } & \multirow{2}{*}{ KG } & \multirow{2}{*}{ Ket } \\
\hline & I & II & III & IV & IV & VI & VII & & \\
\hline \multicolumn{10}{|l|}{ I. Kegiatan Belajar Mengajar } \\
\hline \multicolumn{10}{|l|}{ A. Kegiatan Awal } \\
\hline $\begin{array}{l}\text { Memberi salam dan meminta } \\
\text { salah seorang siswa } \\
\text { mempersiapkan kelas }\end{array}$ & 4 & 4 & 4 & 4 & 4 & 4 & 4 & 4.00 & ST \\
\hline $\begin{array}{l}\text { Memulai pembelajaran dengan } \\
\text { membaca doa }\end{array}$ & 4 & 4 & 4 & 4 & 4 & 4 & 4 & 4.00 & ST \\
\hline Menyanyikan lagu wajib nasional & 4 & 4 & 4 & 4 & 4 & 4 & 4 & 4.00 & ST \\
\hline Mengecek kehadiran siswa & 4 & 4 & 4 & 4 & 4 & 4 & 4 & 4.00 & ST \\
\hline $\begin{array}{l}\text { Menayangkan sebuah video } \\
\text { sebagai apersepsi }\end{array}$ & 4 & 4 & 3 & 3 & 2 & 2 & 2 & 2.86 & $\mathrm{~T}$ \\
\hline $\begin{array}{l}\text { Membuat kelompok siswa secara } \\
\text { heterogen yang terdiri dari } 4-5 \\
\text { orang siswa dalam } 1 \text { kelompok }\end{array}$ & 4 & 4 & 4 & 4 & 4 & 4 & 4 & 4.00 & ST \\
\hline $\begin{array}{l}\text { Menyarankan kepada siswa untuk } \\
\text { membaca sejarah tokoh }\end{array}$ & 4 & 4 & 4 & 3 & 3 & 3 & 3 & 3.43 & $\mathrm{~T}$ \\
\hline
\end{tabular}


Histogram: Jurnal Pendidikan Matematika, 2 (2), 2018 - 202

Ulfiana Yusuf, Andi Tenriawaru

matematika dalam buku paket

yang berhubungan dengan materi

Mengecek pengetahuan siswa

tentang materi prasyarat

$\begin{array}{lllllll}3 & 3 & 3 & 3 & 4 & 4 & 4\end{array}$

$3.43 \mathrm{~T}$

(apersepsi)

Menyampaikan Kompetensi

Dasar dan Tujuan pembelajaran

$\begin{array}{lllllllll}4 & 4 & 4 & 4 & 3 & 3 & 4 & 3.71 & \text { ST }\end{array}$

\section{B. KEGIATAN INTI}

Menampilkan

$\begin{array}{llllllllll}\text { gambar/benda/informasi berkaitan } & 4 & 4 & 4 & 4 & 4 & 4 & 4 & 4.00 & \text { ST }\end{array}$

dengan materi

Memberikan pertanyaan kritis

dari gambar tersebut untuk

memancing pengetahuan siswa

$\begin{array}{lllllllll}3 & 3 & 3 & 3 & 3 & 3 & 4 & 3.14 & \mathrm{~T}\end{array}$

\begin{tabular}{llllllllll}
\hline Menjelaskan secara singkat materi & 4 & 4 & 4 & 4 & 4 & 3 & 4 & 3.86 & ST
\end{tabular}

Siswa di motivasi untuk

mengajukan pertanyaan apa saja

yang belum diketahui terkait

dengan materi pelajaran yang

berlangsung

\begin{tabular}{llllllllll}
\hline Membagikan LKPD & 4 & 4 & 4 & 4 & 4 & 4 & 4 & 4 & ST \\
\hline
\end{tabular}

Memberikan umpan balik, meluruskan, memberi penguatan, serta memberi penjelasan yang

$\begin{array}{lllllllll}4 & 4 & 3 & 3 & 3 & 4 & 4 & 3.57 & \text { ST }\end{array}$

lebih luas

\begin{tabular}{lccccccccc}
\hline $\begin{array}{l}\text { Membantu siswa untuk membuat } \\
\text { kesimpulan }\end{array}$ & 3 & 3 & 3 & 3 & 3 & 4 & 3 & 3.14 & $\mathrm{~T}$ \\
\hline $\begin{array}{l}\text { Memberikan tes tertulis untuk } \\
\text { mengukur ketercapaian tujuan } \\
\text { pembelajaran }\end{array}$ & 3 & 3 & 3 & 3 & 3 & 3 & 3 & 3.00 & $\mathrm{~T}$ \\
\hline C. Kegiatan Akhir & & & & & & & & & \\
\hline $\begin{array}{l}\text { Merefleksi pembelajaran bersama } \\
\text { siswa }\end{array}$ & 4 & 4 & 3 & 3 & 3 & 4 & 4 & 3.57 & $\mathrm{ST}$ \\
\hline $\begin{array}{l}\text { Menyampaikan materi } \\
\text { selanjutnya }\end{array}$ & 4 & 4 & 4 & 4 & 4 & 4 & 4 & 4.00 & $\mathrm{ST}$ \\
\hline $\begin{array}{l}\text { Mengajak siswa untuk berdoa } \\
\text { setelah menerima materi pelajaran }\end{array}$ & 4 & 4 & 4 & 4 & 4 & 4 & 4 & 4.00 & $\mathrm{ST}$ \\
\hline II. SUASANA KELAS & 3 & 4 & 4 & 4 & 4 & 4 & 4 & 3.86 & $\mathrm{ST}$ \\
\hline Siswa antusias & 3 & 4 & 3 & 4 & 4 & 4 & 4 & 3.71 & $\mathrm{ST}$ \\
\hline Guru antusias & 3 & 3 & 3 & 3 & 3 & 3 & 3 & 3.00 & $\mathrm{~T}$ \\
\hline Kegiatan sesuai alokasi waktu & 4 & 3 & 3 & 3 & 3 & 4 & 3 & 3.29 & $\mathrm{~T}$ \\
\hline $\begin{array}{l}\text { Kegiatan sesuai skenario pada } \\
\text { RPP }\end{array}$ & RATA-RATA & & & & & & 3,47 & $\mathrm{~T}$ \\
\hline
\end{tabular}

Sumber: Data Primer, Tahun: 2018

Copyright (C) 2018, Histogram: Jurnal Pendidikan Matematika ISSN: 2549-6700 (print), ISSN 2549-6719 (online) 
Histogram: Jurnal Pendidikan Matematika, 2 (2), 2018 - 203

Ulfiana Yusuf, Andi Tenriawaru

Dari hasil analisis yang ditunjukkan pada Tabel 3 dan berdasarkan kriteria yang ditetapkan, maka dapat disimpulkan bahwa penampilan guru dapat dipertahankan.

3. Data Aktivitas Siswa pada Kegiatan Ujicoba

Hasil pengamatan terhadap aktivitas siswa secara ringkas dapat dilihat pada tabel berikut:

Tabel 4 Aktivitas Siswa Selama Kegiatan Pembelajaran

\begin{tabular}{|c|c|c|c|c|c|c|c|c|c|}
\hline \multicolumn{10}{|c|}{ Persentase Waktu Rata-rata Jenis Aktivitas Siswa } \\
\hline Kategori Aktivitas Siswa & I & II & III & IV & $\mathrm{V}$ & VI & VII & RT & PWI \\
\hline $\begin{array}{l}\text { Memberi salam dan memulai } \\
\text { pembelajaran dengan } \\
\text { membaca doa }\end{array}$ & 2 & 2 & 1 & 1 & 2 & 1 & 1 & 1 & $1-3$ \\
\hline $\begin{array}{l}\text { Menyanyikan lagu wajib } \\
\text { nasional }\end{array}$ & 2 & 2 & 1 & 1 & 1 & 1 & 1 & 1 & $1-3$ \\
\hline Literasi & 6 & 8 & 8 & 10 & 10 & 10 & 10 & 9 & $8-15$ \\
\hline $\begin{array}{l}\text { Mengamati } \\
\text { gambar/benda/informasi yang } \\
\text { ditampilkan oleh guru (literasi) }\end{array}$ & 4 & 4 & 4 & 5 & 6 & 6 & 6 & 5 & $4-10$ \\
\hline $\begin{array}{l}\text { bertanya kapan saja pada hal- } \\
\text { hal yang berhubungan dengan } \\
\text { materi (komunikasi) }\end{array}$ & 6 & 6 & 6 & 8 & 8 & 9 & 8 & 7 & $6-12$ \\
\hline $\begin{array}{l}\text { menanggapi pertanyaan kritis } \\
\text { dari guru untuk memancing } \\
\text { pengetahuan siswa (berfikir } \\
\text { kritis) }\end{array}$ & 9 & 9 & 9 & 8 & 10 & 10 & 12 & 10 & $6-12$ \\
\hline $\begin{array}{l}\text { Aktif berdiskusi secara } \\
\text { berkelompok mengerjakan } \\
\text { LKPD (kerjasama) }\end{array}$ & 10 & 10 & 8 & 8 & 10 & 12 & 12 & 10 & $6-12$ \\
\hline $\begin{array}{l}\text { Menggunakan informasi yang } \\
\text { telah diperoleh untuk } \\
\text { menjawab pertanyaan yang } \\
\text { diberikan oleh guru dalam } \\
\text { LKPD (kerja keras) }\end{array}$ & 4 & 4 & 5 & 6 & 5 & 8 & 8 & 6 & $4-10$ \\
\hline $\begin{array}{l}\text { Menyampaikan jawaban atas } \\
\text { pertanyaan pada LKPD di } \\
\text { depan kelas secara lisan } \\
\text { dan/atau tertulis (komunikasi) }\end{array}$ & 4 & 4 & 5 & 4 & 6 & 6 & 6 & 5 & $4-10$ \\
\hline $\begin{array}{l}\text { Membuat kesimpulan } \\
\text { (kreatifitas) }\end{array}$ & 2 & 2 & 1 & 1 & 2 & 1 & 1 & 1 & $1-3$ \\
\hline $\begin{array}{l}\text { Mengerjakan tugas } \\
\text { (tanggungjawab, } \\
\text { tanggungjawab) }\end{array}$ & 1 & 2 & 1 & 1 & 2 & 2 & 2 & 2 & $1-3$ \\
\hline
\end{tabular}

Sumber: Data Primer, Tahun: 2018 


\section{Histogram: Jurnal Pendidikan Matematika, 2 (2), 2018 - 204 Ulfiana Yusuf, Andi Tenriawaru}

Dari Tabel 4 di atas, diketahui bahwa semua kategori aktivitas siswa yang diamati memenuhi Interval Toleransi PWI (\%) yang ditentukan. Artinya, kriteria pencapaian waktu ideal aktivitas siswa tercapai.

4. Respon siswa terhadap kegiatan pembelajaran

Terdapat 3 aspek respon siswa yaitu terhadap pelajaran matematika, tentang Buku Siswa dan Lembar Kerja Peserta Didik, dan tentang cara guru mengajar, sehingga disimpulkan bahwa siswa memiliki respon positif terhadap perangkat pembelajaran matematika berbasis penguatan pendidikan karakter yang berorientasi pada kecakapan $\operatorname{abad} 21$.

Berdasarkan kriteria keefektifan, maka dapat disimpulkan bahwa perangkat pembelajaran matematika berbasis penguatan pendidikan karakter yang berorientasi pada kecakapan abad 21 bersifat efektif, dimana semua komponen keefektifan perangkat terpenuhi dan komponen (1) yaitu ketuntasan klasikal yang menjadi syarat utama terpenuhi. Selain itu, berdasarkan kriteria kepraktisan, maka dapat disimpulkan pula bahwa perangkat pembelajaran matematika berbasis penguatan pendidikan karakter yang berorientasi pada kecakapan abad 21 bersifat praktis, dimana semua komponen kepraktisan perangkat terpenuhi.

\section{KESIMPULAN DAN SARAN}

\section{A. Kesimpulan}

Perangkat pembelajaran matematika yang dikembangkan berbasis Penguatan Pendidikan Karakter (PPK) yang Berorientasi Pada Kecakapan Abad 21 pada pokok bahasan Bilangan dalam penelitian ini meliputi: Buku siswa, Lembar Kegiatan Peserta Didik (LKPD), dan Rencana Pelaksanaan Pembelajaran (RPP). Pengembangan perangkat ini menggunakan model Thiagarajan atau 4-D yang meliputi empat tahap yaitu (1) tahap pembatasan yang mencakup lima langkah, yaitu: analisis awal akhir, analasis siswa, analisis konsep, analisis tugas, dan spesifikasi tujuan pembelajaran; (2) tahap perancangan yang mencakup empat langkah, yaitu: penyusunan tes, pemilihan media, pemilihan format, dan perencanaan awal; (3) tahap pengembangan yang mencakup tiga langkah, yaitu: penilaian ahli/validasi sebanyak dua kali dan ujicoba; dan (4) tahap penyebaran, namun pada penelitian ini tahap penyebaran hanya sosialisasi terbatas pada guru. 
Histogram: Jurnal Pendidikan Matematika, 2 (2), 2018 - 205

Ulfiana Yusuf, Andi Tenriawaru

Hasil pengembangan diperoleh bahwa perangkat pembelajaran berbasis penguatan pendidikan karakter yang berorientasi pada kecakapan abad 21 bersifat efektif dan praktis dengan Skor rata-rata yang diperoleh siswa pada tes hasil belajar adalah 80,50 yang menunjukkan bahwa ketuntasan klasikal tercapai, aktivitas siswa berada dalam kategori aktif, pada umumnya siswa memberikan respon yang positif terhadap perangkat pembelajaran yang digunakan dan tingkat kemampuan guru dalam mengelola proses pembelajaran berbasis penguatan pendidikan karakter yang berorientasi pada kecakapan abad 21 termasuk dalam kategori tinggi.

\section{B. Saran}

1. Perangkat pembelajaran yang telah dihasilkan sebaiknya diujicobakan di sekolahsekolah lain.

2. Para peneliti selanjutnya dan guru matematika sebaiknya mengembangkan perangkat pembelajaran matematika pada pokok bahasan lain dengan melakukan ujicoba berkaliberkali sehingga didapatkan perangkat pembelajaran matematika yang layak untuk digunakan dan dilakukan sampai pada tahap penyebaran. 
Histogram: Jurnal Pendidikan Matematika, 2 (2), 2018 - 206

Ulfiana Yusuf, Andi Tenriawaru

\section{DAFTAR PUSTAKA}

Anwar, ilham. (2010). Pengembangan Bahan Ajar. Bahan Kuliah Online. Bandung: direktori UPI

Darmiatun, (2013). Menyusun Model Bahan Ajar untuk Persiapanguru dalam Mengajar. Yogyakarta: gava media.

Indrayanti, Norma Y dan Endang Susilowati. 2010. Pengembangan Modul. Surakarta: Tim Pengabdian Kepada Masyarakat LPPM UNS.

OECD. (2013). PISA 2015. Draft MathematicsFramework. Paris: OECD.org. Santyasa, W. (2008). Pengembangan Modul Siswa. (Online). (www.docstoc.com) TIM PPK Kemendikbud, 2017. Modul Pelatihan Penguatan Pendidikan Karakter. Jakarta: Kemdikbud.

Wardani, Sri dan Rumiati. (2011). Instrument Penilaiaan Hasil Belajar Matematika SMP Belajar dari PISA dan TIMSS. Yogyakarta: PPPPTK-Kemdikbud. 